\title{
Diagnosing and Treating Depression and Anxiety in Patients with Cardiovascular Disorders and Diabetes Mellitus in Primary Healthcare: Is Training of Physicians Enough for Improvement?
}

\author{
Диагностика и лечение депрессивных и тревожных расстройств у пациентов \\ с сердечно-сосудистыми заболеваниями и сахарным диабетом в условиях \\ первичной медицинской сети: улучшит ли ситуацию обучение врачей? \\ doi: $10.17816 / C P 112$
}

Original research

Olga A. Karpenko, ${ }^{1}$ Oleg G. Melikhov, ${ }^{2}$ Andrej A. Tyazhelnikov, ${ }^{3}$ Georgiy P. Kostyuk ${ }^{1}$

${ }^{1}$ Mental Health Clinic No.1 named after N.A. Alexeev, Moscow, Russia

2 League of Clinical Research, Institute of Clinical Research, Moscow, Russia

${ }^{3}$ Consultative Diagnostic Polyclinic \#121 of Moscow Healthcare Department, Moscow, Russia

The article can be used under the CC BY-NC-ND 4.0 license (c) Authors, 2021
Ольга А. Карпенко, ${ }^{1}$ Олег Г. Мелихов, ${ }^{2}$ Андрей А. Тяжельников, ${ }^{3}$ Георгий П. Костюк ${ }^{1}$

1 ГБУЗ «ПКБ № 1 им. Н.А. Алексеева ДЗМ», Москва, Россия

2 Лига содействия клиническим исследованиям, Москва, Россия

з ГБУЗ «КДП № 121 ДЗМ», Москва, Россия

Личензия CC BY-NC-ND 4.0

(๖) Коллектив авторов, 2021

\section{ABSTRACT}

INTRODUCTION: Common mental disorders - anxiety and depression - are prevalent among patients with cardiovascular disease (CVD) and diabetes mellitus type 2 (DM) and can negatively influence treatment outcomes and healthcare expenses. Despite the importance of management of depression and anxiety in primary care facilities, the diagnostics and treatment of these disorders remain insufficient in the Russian Federation.

OBJECTIVE: To explore whether the rates of referrals to psychiatrists and indicated pharmacological treatment received due to depression or anxiety among patients with CVD and DM will significantly change in primary healthcare facilities after the training of primary care physicians (PCPhs) to deal with comorbid depression and anxiety (including the algorithm for referral to a psychiatrist).

METHODS: Patients in primary care outpatient settings with diagnoses of CVD and DM passed screening on anxiety and depression using the Hospital Anxiety and Depression Scale (HADS), and information about the indicated treatment for anxiety or depression was collected when present (Sample 1: $n=400$ ). The educational programme for PCPhs on the diagnostics of anxiety and depression was then performed, and PCPhs were instructed to refer patients with 
HADS $>7$ to a psychiatrist. After the training, the second sample was collected (Sample 2: $n=178$ ) using the same assessments as for Sample 1. The independent expert (psychiatrist) evaluated whether the patients had received the indicated pharmacological treatment according to the screening criteria used in the study for anxiety and depression for both samples.

RESULTS: The proportions of patients with borderline abnormal and abnormal HADS scores (> 7) were 365 (91.2\%) and 164 (92.1\%) in Sample 1 and Sample 2, respectively. In Sample 1, among patients with HADS > 7, 119 (29.8\%) received psychopharmacological treatment, but in only 46 (38.7\%) cases was it indicated in compliance with the screening criteria. In Sample 2, among patients with HADS > 7, 59 (33.1\%) received psychopharmacological treatment, and in only $14(23.7 \%)$ cases was it indicated in compliance with the screening criteria. The differences in the indicated pharmacological treatment were not statistically significant, and no one from Sample 2 with HADS $>7$ met a psychiatrist through PCPh referral.

CONCLUSIONS: Anxiety and depression are prevalent in patients with CVD and DM treated in primary care facilities, but these patients may not be receiving the indicated pharmacological treatment. Barriers to referral and the use of psychiatric consultation exist despite the focused training of PCPhs and the straightforward referral protocol provided.

\section{АННОТАЦИЯ}

ВВЕДЕНИЕ: Тревога и депрессия, являясь распространенными психическими расстройствами, широко представлены среди пациентов с сердечно-сосудистыми заболеваниями (СС3) и сахарным диабетом 2 типа (СД), они негативно влияют на результаты лечения и приводят к повышенным затратам со стороны системы здравоохранения. Несмотря на важность диагностики и лечения тревожных и депрессивных расстройств на уровне первичного звена медицинской помощи, в Российской Федерации эта проблема до сих пор не решена.

ЦЕЛЬ: Исследовать, изменится ли количество направлений к психиатру и число случаев корректного лечения депрессивных и тревожных расстройств у пациентов первичной медицинской сети с ССЗ и СД после обучения врачей поликлиник ведению пациентов с коморбидными депрессивными и тревожными расстройствами (включая алгоритм направления к психиатру).

МЕТоДЫ: На первом этапе исследования пациентам с ССЗ и СД, проходящим лечение в поликлинике, проводили скрининг на выявление тревоги и депрессии при помощи Госпитальной Шкалы Тревоги и Депрессии (HADS). Если пациент принимал психофармакотерапию, название лекарства и его доза заносились в карту исследования. Всего было обследовано 400 человек. На втором этапе врачи поликлиники проходили образовательную программу по диагностике тревожно-депрессивных расстройств, в рамках которой они были проинструктированы, что все пациенты с баллами по шкале HADS > 7 должны направляться к психиатру. После обучения на третьем этапе исследования была набрана вторая выборка пациентов ( $n=178)$ с использованием такого же протокола, как и на первом этапе. Независимым экспертом (психиатром) оценивалась адекватность психофармакотерапии у пациентов обеих выборок по результатам скрининга тревоги и депрессии в соответствии с критериями, разработанными для данного исследования.

PEЗУЛЬТАТЫ: Доля пациентов с уровнем тревоги и/или депрессии выше нормального по шкале HADS (> 7) составляла 365 (91,2\%) в первой выборке и 164 (92,1\%) во второй выборке. В первой выборке среди пациентов с HADS > 7119 (29,8\%) человек получали психофармакотерапию, но только у 46 (38,7\%) она соответствовала результатам скрининга. Во второй выборке среди пациентов HADS > 759 (33,1\%) человек получали психофармакотерапию, но только у 14 (23,7 \%) она соответствовала результатам скрининга. Разница 
между выборками по этим показателям не достигала статистической значимости, ни один пациент из второй выборки не был направлен к психиатру.

ЗАКЛЮЧЕНИЕ: Тревога и депрессия часто встречаются У пациентов с ССЗ и СД, обращающихся за лечением в поликлинику, но при этом пациенты не получают адекватную психофармакотерапию. Несмотря на проведение целенаправленного обучения и предоставления врачам поликлиник протокола направления пациентов к психиатру, существуют барьеры осуществления таких направлений и получения пациентами консультаций психиатра.

Keywords: depression; anxiety; primary care; mental-health education; Russia Ключевые слова: депрессия; тревога; первичная помощь; образование в области психического здоровья; Россия

\section{INTRODUCTION}

High rates of anxiety- and depression-related disorders are well-known healthcare problems of our time. The lifetime prevalence of depression in the population is 10-15\%, and is among the top three disorders leading to disability. ${ }^{1}$ The lifetime prevalence of anxiety disorders in the population is up to $33 \%$, with anxiety-related disorders associated with high levels of impairment and excessive healthcare utilization. ${ }^{2}$ Among physical diseases, cardiovascular disease (CVD) and diabetes mellitus type 2 (DM) remain major healthcare concerns worldwide. ${ }^{3,4}$

Thus, depression, anxiety, CVD, and DM are among most prevalent health problems, and their co-occurrence can make the situation even worse. Undiagnosed depression increases the risk of mortality and cardiovascular events in patients with $C V D^{5-7}$ along with a higher rate of health resource utilization; 5 the same is true in patients with DM. ${ }^{8}$ Furthermore, CVD and DM are risk factors for depression. $5,9,10$ Anxiety is associated with poor metabolic outcomes and increased medical complications in $\mathrm{DM}^{11}$ and with adverse cardiovascular outcomes - including death - in CVD. ${ }^{12}$ Therefore, diagnostics and treatments of anxiety and depression are an important healthcare task, especially in cases of comorbidity.

Interaction between general practitioners and mentalhealth professionals, and building an integrated primary care model, is acknowledged as being important to healthcare systems..$^{13-15}$ Based on the evidence of a high prevalence of mental disorders on the one hand, and their insufficient diagnostics and treatment on the other, the WHO launched the Mental Health Gap Action Programme (mhGAP) ${ }^{16}$ in 2008 with the aim of bridging the treatment gap for people with mentalhealth problems by facilitating early detection and treatment of mental disorders. This programme is actively ongoing worldwide, with the education of medical professionals and non-medical staff considered one of the more essential steps within it. 17,18

In Russia, the algorithm for diagnostics and multiprofessional management of non-psychotic mental disorders in primary care settings was developed within the Federal targeted programme, the "Prevention and management of socially significant diseases (2007-2012)", in $2010 .{ }^{19}$ Important factors that should be considered in building integrated care in Russia form the legislative and financial aspects of healthcare. Psychiatry and general medicine have different financing models, and there is a legislation barrier - Mental Health Law prevents non-psychiatrists from treating any mental health disorders themselves. ${ }^{20,21}$

The model of ongoing interaction between psychiatrists and primary care physicians (PCPhs), including the continuous education and guidance of PCPhs in dealing with patients with mentalhealth problems, was suggested and studied ${ }^{22}$ within the above Federal programme. The model required the presence of psychiatrists in primary care settings that was not, however, further implemented in routine medical practice. ${ }^{20}$

According to recent data, anxiety and depression are diagnosed 25-70 times less frequently in Russia than in other countries. ${ }^{23}$ Thus, the problem of insufficient care for patients with common mental disorders remains unsolved. To that end, timely diagnostics of mental disorders in primary care settings and referral to a psychiatrist for treatment may increase care provision to people with depression and anxiety. 
The aim of this study was to explore whether the baseline rates of referrals to psychiatrists and the indicated pharmacological treatment (complying with the screening criteria) received due to depression or anxiety among patients with CVD and DM will significantly change in the primary healthcare facility after the training of PCPhs to deal with comorbid depression and anxiety (including the algorithm for referral to a psychiatrist).

\section{METHODS}

The present study was performed through two crosssectional assessments (each on a different sample of patients) conducted before and after the PCPhs' training.

\section{Study Population}

The study subjects were the consecutive patients seen by PCPhs who met the selection criteria below.

\section{Inclusion Criteria}

- Adults of both sexes, 40-64 years old.

- Admitted to outpatient department to be examined by a primary care physician.

- Having one or more of the following diagnoses according to ICD-10:

$\diamond \quad 110$ Essential (primary) hypertension

$\diamond \quad 111$ Hypertensive heart disease

$\diamond \quad 112$ Hypertensive renal disease

$\diamond \quad 113$ Hypertensive heart and renal disease

$\diamond \quad 115$ Secondary hypertension

$\diamond \quad$ I20 Angina pectoris

$\diamond \quad$ I21 Acute myocardial infarction

$\diamond \quad 122$ Subsequent myocardial infarction

$\diamond \quad$ I23 Certain current complications following acute myocardial infarction

$\diamond \quad$ I24 Other acute ischaemic heart diseases

$\diamond \quad 125$ Chronic ischaemic heart disease

$\diamond \quad$ E11 Type 2 diabetes mellitus.

\section{Instruments}

\section{Data collection}

All the patients consecutively visiting PCPhs who met the inclusion criteria were evaluated for the purposes of this study. Information on sex, age, and prescribed pharmacological treatment for anxiety and/or depression was collected and entered in an electronic Case Report Form (e-CRF). Patients were asked whether they used psychopharmacotherapy and, if so, the generic name and dose of the medication was also entered in e-CRF according to the patients' self-report. This information was related to any psychopharmacological treatment being prescribed to the patient (not only through the referral by PCPh to a psychiatrist in this study). The use of psychosocial interventions (such as psychotherapy) was not evaluated in this study.

\section{Hospital Anxiety and Depression Scale}

Additionally, patients completed the Hospital Anxiety and Depression Scale (HADS) ${ }^{24}$ in an application developed for portable devices (tablets) specially for this study. HADS is a self-report questionnaire designed to screen for anxiety and depression in primary care settings. It consists of seven questions about anxiety and seven questions about depression symptoms during the two weeks prior to completing the questionnaire. Each question has four possible answers that reflect different severities of symptoms, if present, where the minimum score of 0 means no symptoms, and the maximum score of 3 indicates pronounced symptoms. The scores for anxiety and depression are calculated separately, therefore providing the two scores reflecting the levels of anxiety (HADS-A) and depression (HADS-D). The following cut-off scores are recommended: a score of 0-7 indicates normal levels of depression anxiety; a score of 8-10 indicates borderline abnormal levels of depression anxiety; and a score of $>10$ indicates abnormal levels of depression anxiety.

Evaluation of psychopharmacological treatment received by patients

Patient data (from e-CRF) was assessed by an independent expert (psychiatrist). The expert completed the treatment evaluation form in the e-CRF by marking "yes" if the treatment complied with the following criteria (and "no" if this was not the case):

HADS-A and/or HADS-D $<8$, absence of antidepressant/anti-anxiety medication - YES HADS-A and/or HADS-D 8-10, absence of antidepressant/anti-anxiety medication - YES HADS-A and/or HADS-D > 10, antidepressant prescribed - YES

HADS-A $>10$ tranquilizers prescribed - YES

*The off-label use of phenobarbital was noted in some of the patients in the sample, and this was marked with "NO" 
The indicated evaluation criteria were based on the World Federation of Societies of Biological Psychiatry Guidelines for Biological Treatment of Unipolar Depressive Disorders. ${ }^{25}$ It was assumed that patients with HADS $<8$ did not have anxiety or depressive disorder, and therefore that pharmacological treatment would not be needed. Patients with HADS-A in the range of 8-10 may have mild anxiety that, pharmacologically speaking, could be straightforwardly managed by tranquilizers. Patients with HADS-D in the range of 8-10 may have mild depression that would not otherwise need pharmacological treatment. For HADS $>10$, it was assumed that patients have anxiety or depressive disorder that requires pharmacological treatment. The prescription of herbs was included as a pharmacological treatment, but was not relevant for the treatment indication criteria mentioned above, since it is not included in the treatment guidelines ${ }^{25}$ (except for the St. John's Wort, which would be relevant but was not present in the treatment of the study participants).

\section{Study stages and procedures}

The stages and procedures of the study are presented in Figure 1.

\section{Stage 1 - 1st Data Collection (6.08.2020-8.10.2020)}

Sample 1 was recruited as consecutive patients who met the mentioned inclusion criteria. They completed the HADS, and their e-CRF data was collected as described above. The indicated pharmacological treatment for depression or anxiety was entered in the patient's record, if present. All referrals to other specialists were performed as usual (based on the PCPh's clinical evaluation).

Stage 2 - Training of PCPhs and Changing the Pattern of Clinical Care

After analysing the data obtained at Stage 1, Stage 2 of the study was initiated. PCPhs who assessed the patients in Stage 1 passed the training on clinical diagnostics of anxiety and depression, including the instruction to use HADS as a screening tool to detect patients who needed further evaluation for depression and anxiety. A new referral model for patients with abnormal HADS scores was proposed. PCPhs were instructed to refer patients with anxiety (HADS-A) and/or depression (HADS-D) score $>7$ to a psychiatrist in the local mental health dispensary (specialized outpatient mental facility). Referrals could be performed either by advice to visit a psychiatrist or by prescription for a psychiatric consultation on the referral blank, depending on the local referral procedures in the primary care facility.

In the training module, the results of Stage 1 were presented to the PCPhs to make them aware of the level of anxiety and depression among their patients. Training included information about the diagnostic criteria of anxiety and depressive disorders, and evidence of the

\section{1st Data Collection Period}

Education
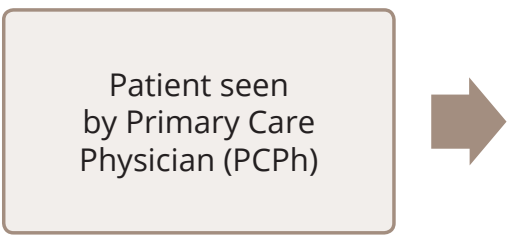

Data Processed and Analyzed (Primary Endpoint assessed by independent expert)
Evaluation of anxiety and depression, information on administered treatment
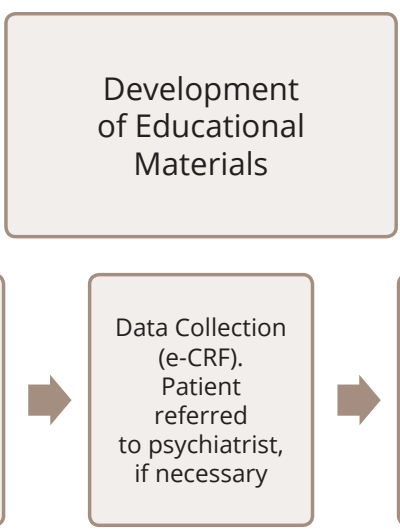
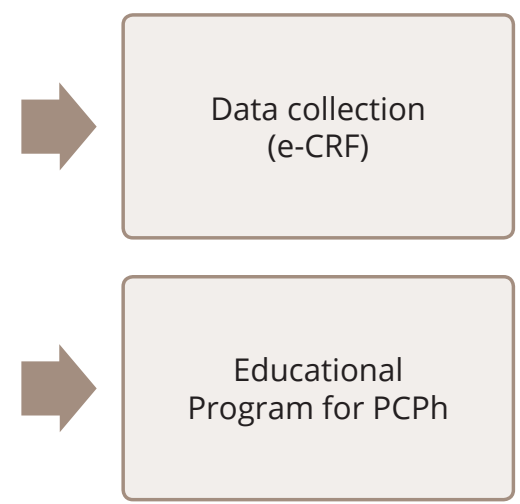

Data Collection (e-CRF). Primary Endpoint assessed by independent expert

Figure 1. Study procedure chart. 
advantages of treatment for patients with abnormal levels of anxiety and depression, both for their mental state and for the successful treatment of CVD and DM. Training included basic communication strategies while speaking about mental health with the patient and motivation technics that could be used in the discussion of the need to treat mental disorders and visit psychiatrists. These were intended to help the PCPhs to start dialogues with their patients about mental health and to encourage them to make appropriate referrals to psychiatrists.

Training was performed in the form of a three-hour lecture that was supplied with an educational video on how to diagnose mental health problems in a primary care setting and on the communication skills needed to discuss these issues with the patient. Motivational techniques for referral to psychiatrics were provided in the video lesson, whilst the referral algorithm was also discussed during the lecture.

Stage 3 - 2nd Data Collection (27.01.2021-18.04.2021) Sample 2 was recruited by the PCPhs involved in Stage 1 and Stage 2 from consecutive patients meeting the inclusion criteria. All information was assessed as per Stage 1.

\section{Setting}

The Consultative Diagnostic Polyclinic \#121 of the Moscow Healthcare Department.

\section{Participants}

During the first data collection period, the data on 400 patients was collected (Sample 1), whilst during the second data collection period, data was collected on 178 patients (Sample 2).

The associated sample characteristics are presented in Table 1.

\section{Statistical analysis}

Descriptive statistics were used for data analysis. Continuous data were presented according to mean, standard deviation, median, and range. Discrete data were presented with absolute and relative frequencies (percentage). The equivalence of the two proportions was tested via a two-sided z-test, whilst differences in frequencies between two groups were tested via a two-sided $\chi^{2}$-test using standard $\mathrm{R}$ language libraries at a significance level of $95 \%$.

\section{Ethical approval}

The study was approved by the Independent Interdisciplinary Ethics Committee on Ethical Review for Clinical Studies (protocol No. 05, 13.03.2020). All patients signed an informed consent form before participation in the study.

\section{RESULTS}

Patients who screened positive ( $>$ 7) on any or both of the HADS scales were comparably represented

Table 1. Patients' demography and HADS scores in the study samples

\begin{tabular}{|c|c|c|}
\hline & Sample 1 & Sample 2 \\
\hline$n$ & 400 & 178 \\
\hline male & $112(28.0 \%)$ & $37(20.8 \%)$ \\
\hline female & $288(72.0 \%)$ & $141(79.2 \%)$ \\
\hline age (Mean (SD; SE)) & $55.8(5.7 ; 0.3)$ & $55.6(6.2 ; 0.5)$ \\
\hline \multicolumn{3}{|l|}{ HADS-D Scores } \\
\hline 0-7 scores - normal & $84(21.0 \%)$ & $39(21.9 \%)$ \\
\hline 8-10 scores - borderline abnormal & $206(51.5 \%)$ & $88(49.4 \%)$ \\
\hline 11-21 scores - abnormal & $110(27.5 \%)$ & $51(28.7 \%)$ \\
\hline \multicolumn{3}{|l|}{ HADS-A Scores } \\
\hline 0-7 scores - normal & $196(49.0 \%)$ & $53(29.8 \%)$ \\
\hline 8-10 scores - borderline abnormal & $142(35.5 \%)$ & $61(34.3 \%)$ \\
\hline 11-21 scores - abnormal & $62(15.5 \%)$ & $64(36.0 \%)$ \\
\hline
\end{tabular}


in both samples: 365 (91.2\%) for Sample 1 versus 164 (92.1\%) for Sample 2, $\left(\chi^{2}=0.124 p=0.72\right)$. Distribution between HADS-D scores was comparable in both samples, whereas the distribution of HADS-A scores differed between the samples. Sample 2 had a significantly higher number of patients with abnormal HADS-A scores $(>10)\left(\chi^{2}=30.2 ; p<0.0001\right)$, and a significantly lower number of normal scores $\left(\right.$ HADS 0-7) $\left(\chi^{2}=18.6 ; p<0.0001\right)$.

The distribution of positive HADS scores depending on CVD and DM diagnoses of patients are presented in Table 2 for both samples. The number of patients with diagnosis 110 Essential (primary) hypertension was significantly lower in Sample 2 compared with Sample 1 $\left(\chi^{2}=15.1 ; p=0.0001\right)$, as was the number of patients with positive HADS scores $(>7)\left(\chi^{2}=12.5 ; p=0.0004\right)$. The number of patients with diagnosis 111 Hypertensive heart disease was significantly higher in Sample 2 compared to Sample $1 \quad\left(\chi^{2}=4.6 ; p=0.03\right)$, as was the number of patients with positive HADS scores $(>7)\left(\chi^{2}=4.4\right.$; $p=0.04)$. Other differences between the two samples were not found to be statistically significant.

The number of patients with the prescribed psychopharmacological treatment and the number of patients where this treatment was indicated according to the study criteria upon the expert evaluation for both samples are presented in Table 3.

Although it was expected that patients from Sample 2 with a HADS-A/HADS-D > 7 would be referred to a psychiatrist for diagnostics and treatment prescription or correction, no one from Sample 2 actually met the psychiatrist through the PCPhs' referrals.

Table 2. HADS scores and diagnoses of patients in the samples

\begin{tabular}{|c|c|c|c|c|c|c|}
\hline \multirow[b]{2}{*}{ Diagnoses } & \multicolumn{3}{|l|}{ Sample 1} & \multicolumn{3}{|l|}{ Sample 2} \\
\hline & Total & $\begin{array}{l}\text { HADS-A } \\
\text { and/or } \\
\text { HADS-D }<7\end{array}$ & $\begin{array}{l}\text { HADS-A } \\
\text { and/or } \\
\text { HADS-D > } 7\end{array}$ & Total & $\begin{array}{l}\text { HADS-A } \\
\text { and/or } \\
\text { HADS-D }<7\end{array}$ & $\begin{array}{l}\text { HADS-A } \\
\text { and/or } \\
\text { HADS-D > } 7\end{array}$ \\
\hline$n$ & 400 & 35 & 365 & 178 & 14 & 164 \\
\hline $\begin{array}{l}\text { I10 } \\
\text { Essential (primary) hypertension }\end{array}$ & $84(21.0 \%)^{\star \star}$ & $7(20.0 \%)$ & $77(21.1 \%)^{\star \star}$ & $14(7.9 \%)^{\star \star}$ & $0(0.0 \%)$ & $14(8.5 \%)^{\star \star}$ \\
\hline $\begin{array}{l}\text { I11 } \\
\text { Hypertensive heart disease }\end{array}$ & $316(79.0 \%)^{*}$ & $28(80.0 \%)$ & $288(78.9 \%)^{\star}$ & $154(86.5 \%)^{*}$ & $12(85.7 \%)$ & $142(86.6 \%)^{*}$ \\
\hline $\begin{array}{l}\text { I12 } \\
\text { Hypertensive renal disease }\end{array}$ & $11(2.8 \%)$ & $0(0.0 \%)$ & $11(3.0 \%)$ & $1(0.6 \%)$ & $0(0.0 \%)$ & $1(0.6 \%)$ \\
\hline $\begin{array}{l}\text { I13 } \\
\text { Hypertensive heart and renal disease }\end{array}$ & $15(3.8 \%)$ & $0(0.0 \%)$ & $15(4.1 \%)$ & $0(0.0 \%)$ & $0(0.0 \%)$ & $0(0.0 \%)$ \\
\hline $\begin{array}{l}\text { I15 } \\
\text { Secondary hypertension }\end{array}$ & $9(2.3 \%)$ & $0(0.0 \%)$ & $9(2.5 \%)$ & $1(0.6 \%)$ & $0(0.0 \%)$ & $1(0.6 \%)$ \\
\hline $\begin{array}{l}120 \\
\text { Angina pectoris }\end{array}$ & 42 (10.5\%) & $4(11.4 \%)$ & $38(10.4 \%)$ & $14(7.9 \%)$ & $3(21.4 \%)$ & $11(6.7 \%)$ \\
\hline $\begin{array}{l}\text { I21 } \\
\text { Acute myocardial infarction }\end{array}$ & $11(2.8 \%)$ & $0(0.0 \%)$ & $11(3.0 \%)$ & $4(2.2 \%)$ & $1(7.1 \%)$ & $3(1.8 \%)$ \\
\hline $\begin{array}{l}122 \\
\text { Subsequent myocardial infarction }\end{array}$ & $5(1.3 \%)$ & $0(0.0 \%)$ & $5(1.4 \%)$ & $1(0.6 \%)$ & $0(0.0 \%)$ & $1(0.6 \%)$ \\
\hline $\begin{array}{l}\text { I23 } \\
\text { Certain current complications } \\
\text { following acute myocardial infarction }\end{array}$ & $5(1.3 \%)$ & $0(0.0 \%)$ & $5(1.4 \%)$ & $0(0.0 \%)$ & $0(0.0 \%)$ & $0(0.0 \%)$ \\
\hline $\begin{array}{l}\text { I24 } \\
\text { Other acute ischaemic heart diseases }\end{array}$ & $19(4.8 \%)$ & $2(5.7 \%)$ & $17(4.7 \%)$ & $2(1.1 \%)$ & $0(0.0 \%)$ & $2(1.2 \%)$ \\
\hline $\begin{array}{l}\text { I25 } \\
\text { Chronic ischaemic heart disease }\end{array}$ & $50(12.5 \%)$ & $6(17.1 \%)$ & $44(12.1 \%)$ & $28(15.7 \%)$ & $5(35.7 \%)$ & $23(14.0 \%)$ \\
\hline $\begin{array}{l}\text { E11 } \\
\text { Type } 2 \text { diabetes mellitus }\end{array}$ & $100(25.0 \%)$ & $7(20.0 \%)$ & $93(25.5 \%)$ & $33(18.5 \%)$ & $1(7.1 \%)$ & $32(19.5 \%)$ \\
\hline
\end{tabular}

$* p<0.05, * * p<0.001$ 
Table 3. Prescribed pharmacological treatment for anxiety and depression and its indication according to the study criteria

\begin{tabular}{|c|c|c|c|c|c|c|}
\hline & \multicolumn{3}{|l|}{ Sample 1} & \multicolumn{3}{|l|}{ Sample 2} \\
\hline & Total & HADS $<7$ & HADS $>7$ & Total & HADS $<7$ & HADS $>7$ \\
\hline \multicolumn{7}{|c|}{ Psychopharmacological treatment prescribed } \\
\hline$n$ & 400 & 35 & 365 & 178 & 14 & 164 \\
\hline yes & $119(29.8 \%)$ & $9(25.7 \%)$ & $110(30.1 \%)$ & $59(33.1 \%)$ & $3(21.4 \%)$ & $56(34.1 \%)$ \\
\hline \multicolumn{7}{|c|}{ Psychopharmacological treatment indicated by the study criteria } \\
\hline$n$ & 119 & 9 & 110 & 59 & 3 & 56 \\
\hline yes & 46 (38.7\%) & $7(77.8 \%)$ & 39 (35.5\%) & 14 (23.7\%) & 2 (66.7\%) & $12(21.4 \%)$ \\
\hline
\end{tabular}

There was no significant difference between samples in terms of the proportion of patients who received the indicated pharmacological treatment according to the study criteria $\left(\chi^{2}=2.8 ; p=0.09\right)$.

\section{DISCUSSION}

The results of the study revealed a high proportion of patients with CVD and DM having HADS-A and/or HADS-D scores $>7$ in both study samples (91.2\% and $92.1 \%$, respectively). One-third of the patients with the positively screened HADS scores received psychopharmacological treatment, but only in $21.4 \%$ $35.5 \%$ cases was the treatment indicated in compliance with the screening criteria used in this study. The training of PCPhs did not seem to affect the pattern of delivery of care offered to the patients in Sample $2-$ no one in this sample received a consultation with a psychiatrist through a PCPh referral, nor received the indicated pharmacological treatment to any greater extent than the patients in Sample 1.

The level of positively screened (borderline or abnormal) anxiety and/or depression according to $\operatorname{HADS}(>7)$ reveled by our study exceeds the known rates of in CVD observed in other studies that used the same screening tool (47.2\% for anxiety and $42.5 \%$ for depression). ${ }^{26}$ The level of abnormal anxiety and/or depression according to HADS (> 10) revealed by our study also differs from the known data. ${ }^{27}$ Our results may partly be explained by the fact that our study was performed during the COVID-19 pandemic. On the one hand, the pandemic was a stressor that could have increased levels of anxiety and depression among patients; on the other, only those patients with more pronounced health problems would have been seeking medical help during the pandemic. ${ }^{28}$ This may explain why in our study depression, according to HADS, was more frequent than anxiety, whereas in the mentioned studies anxiety was more frequent than depression. ${ }^{26,27}$

When it comes to the number of the patients who received the indicated pharmacological treatment for probably having anxiety and depressive disorder in our study, this corresponds with known data from previous studies on the treatment of depression in primary care. ${ }^{14,29}$

The fact that patients did not meet the psychiatrists through PCPh referral after PCPhs were trained to detect depression and anxiety and to perform referrals may be due to several reasons. First, the brief education provided might not have been sufficient to change their patterns of care delivery. More interactive training may be needed, with feedback on how much the PCPhs have actually understood the concepts, and how much they have developed the skills needed for the implementation of the proposed protocols. Furthermore, their learning achievement may have to be continuously monitored, and may require more time for the implementation of knowledge and the change to be visible. Second, the segregation of mental health and general medicine services that leads to organizational difficulties in referrals and territorial separation of community mental health facilities (dispensaries) from primary care facility may add to the risk of patients' non-compliance with the PCPhs' recommendations to visit a psychiatrist. Finally, patients' and physicians' stigma-related fears may be a serious barrier to getting a psychiatric consultation. 30

The effect of PCPhs' mental health training is studied within the WHO mhGAP initiative in low-to-middle income countries, ${ }^{31}$ and the number of referrals to specialized care is one of the estimated outcomes in some studies.32,33 Interestingly, referrals of patients with mental health 
problems from primary to specialized care is seen as an undesirable effect of training, since it is associated with a reduction in PCPhs' capacity to deal with psychiatric disorders, reduced knowledge, work experience, and poorer attitude towards mental health problems, ${ }^{32,34}$ contrary to hospital settings where referrals to psychiatrist are welcomed. ${ }^{35}$ In our study, the referral to a psychiatrist in primary care settings would be seen as a desirable effect of PCPhs' training, taking into consideration the Russian healthcare system's particular features such as restrictions on non-psychiatrists being allowed to treat mental disorders. Therefore, the differences in healthcare systems between the countries may make it difficult to make direct international comparisons of the study results.

Our research has several limitations. First, the assumptions of the presence of depression and/or anxiety and judgments on the pharmacological treatment being correctly indicated were based solely on the HADS score which, even though it is a valid screening tool, is not a substitute for clinical diagnostics and assessment. Second, the study was performed during the COVID-19 pandemic, a major unpredicted confounding factor that changed overall patterns of care delivery in primary care settings. This extraordinary situation led to physicians being overloaded with work, significant changes in patient flows, and reduced availability of non-urgent medical care. ${ }^{36,37}$ Working conditions during the pandemic could have influenced doctors' ability to acquire the new skill of patient referral to psychiatrists that, even in more normal situations, would meet considerable resistance due to stigma-related issues. ${ }^{38,39}$ Third, the information about psychopharmacological treatment was collected according to the patients' self-reports, and was limited purely to the drug name and dose, with no mental health history collected. Fourth, no information on psychosocial treatments that patients may have had (supportive counseling, individual or group psychotherapy, etc.) were collected during the study, and these procedures may have affected the further need for pharmacological treatment, since contemporary guidelines suggest that for mild to moderate cases of depression, psychosocial intervention should be used as the first line of treatment. 40,41

In spite of these limitations, this study did have several advantages. It is the first study to our knowledge whose aim was to assess the effect of training of PCPhs with straightforward instructions and guidelines to perform patient referrals for those who screened positively for depression and anxiety to a psychiatrist. Furthermore, this study was performed in naturalistic primary care settings, and all study procedures were adjusted to the routine working conditions of PCPhs. In addition, the specifics of the Russian healthcare system, with the need to refer all patients with suspected mental health problems to psychiatrists, was considered.

\section{CONCLUSION}

The study revealed high levels of anxiety and depression in patients with CVD and DM undergoing treatment in primary care facilities, and a lack of the prescribed indicated pharmacological treatments for these conditions. Barriers to referrals for consultation with psychiatrists do exist, despite PCPhs' focused training and an otherwise straightforward referral protocol.

The study results indicated several requirements for primary care practice and healthcare. The high levels of depression and anxiety in patients with CVD and DM revealed by the screening in a primary care setting may point to the need for more careful diagnostics of anxiety and depression disorders in routine primary care. The brief training that the $\mathrm{PCPhs}$ received may not be sufficient to make a difference in healthcare delivery patterns, implying the need for more profound training of physicians in the diagnostics and treatment of common mental disorders and, indeed, in motivating patients to visit mental health professionals. The physicians' skills acquisition may have to be monitored and evaluated on an ongoing basis, with problem-solving interventions provided where needed. More research is needed to identify and evaluate the most efficient ways to train physicians in the early recognition of and intervention related to anxiety and depression among patients with CVD and DM. Furthermore, closer interactions between mental health professionals and PCPh may be needed to overcome the barriers to referring patients with mental health problems to psychiatrists. Finally, more research is needed to identify the barriers in receiving treatment in specialized community mental health settings for patients and in physicians making referrals.

Article history:

Submitted: 27.10.2021

Accepted: 12.12 .2021

Published: 21.12.2021 
Funding: The study was funded by a Pfizer grant.

Conflict of interest: The authors received funding from a Pfizer grant for the study.

Authors" contributions: O.A. Karpenko - manuscript writing; O.G. Melikhov - methodology of the study, manuscript editing; A.A. Tyazhelnikov, G.P. Kostyuk study concept and supervision, manuscript editing.

\section{For citation:}

Karpenko OA, Melikhov OG, Tyazhelnikov AA, Kostyuk GP. Diagnosing and Treating Depression and Anxiety in Patients with Cardiovascular Disorders and Diabetes Mellitus in Primary Healthcare: Is Training of Physicians Enough for Improvement? Consortium Psychiatricum. 2021;2(4):3-13. doi: 10.17816/CP112

\section{Information about authors}

O.G. Melikhov, The head of Scientific Society "The League of Clinical Research"; Director, Institute of Clinical Research; Director, Center of Scientific Methodology, N.A. Semashko National Research Institute of Public Health, ORCID: https://orcid.org/0000-0001-9442-7707

A.A. Tyazhelnikov, MD, PhD, Director of Consultative Diagnostic Polyclinic \#121 of Moscow Healthcare Department, chief expert in primary care of Moscow Healthcare Department, ORCID: https://orcid.org/0000-0002-2191-0623, Scopus Author ID: 57200694228

G.P. Kostyuk, Professor of Psychiatry, Director of Mental-health Clinic No. 1 named after N.A. Alexeev of Moscow Healthcare Department, chief expert in psychiatry of Moscow Healthcare Department, ORCID: https://orcid.org/0000-0002-3073-6305, Scopus Author ID: 57200081884, RSCI: 3424-4544

\section{Correspondence to:}

O.A. Karpenko, MD, PhD, The head of scientific collaborations department, Mentalhealth Clinic No. 1 named after N.A. Alexeev of the Moscow Healthcare Department, ORCID: https://orcid.org/0000-0002-0958-0596, Scopus Author ID: 56654984500, RSCI: 9600-0688

E-mail: drkarpenko@gmail.com

\section{References}

1. Smithson S, Pignone MP. Screening Adults for Depression in Primary Care. Med Clin North Am. 2017;101(4):807-821. doi: 10.1016/j.mcna.2017.03.010

2. Bandelow B, Michaelis S. Epidemiology of anxiety disorders in the 21st century. Dialogues in Clinical Neuroscience. 2015;17(3):327-335. doi: 10.31887/DCNS.2015.17.3/bbandelow

3. Townsend N, Kazakiewicz D, Lucy Wright F, et al. Epidemiology of cardiovascular disease in Europe. Nat Rev Cardiol. 2021. doi: 10.1038/s41569-021-00607-3

4. Khan MAB, Hashim MJ, King JK, et al. Epidemiology of Type 2 Diabetes - Global Burden of Disease and Forecasted Trends. J Epidemiol Glob Health. 2020;10(1):107-111. doi: 10.2991/jegh.k.191028.001
5. Okunrintemi V, Valero-Elizondo J, Michos ED, et al. Association of Depression Risk with Patient Experience, Healthcare Expenditure, and Health Resource Utilization Among Adults with Atherosclerotic Cardiovascular Disease. J Gen Intern Med. 2019;34(11):2427-2434. doi: 10.1007/s11606-019-05325-8

6. Chazov El, Oganov RG, Pogosova GV, et al. Klinikoepidemiologicheskaya programma izucheniya depressii v kardiologicheskoi praktike u bol'nykh arterial'noi gipertoniei i ishemicheskoi bolezn'yu serdtsa (KOORDINATA): rezul'taty mnogotsentrovogo issledovaniya. Kardiologiya. 2007;(3):28-37.

7. Oganov RG, Pogosova GV, Koltunov IE, et al. Depressivnaya simptomatika ukhudshaet prognoz serdechno-sosudistykh zabolevanii i snizhaet prodolzhitel'nost' zhizni bol'nykh arterial'noi gipertoniei i ishemicheskoi bolezn'yu serdtsa. Kardiologiya. 2011;(2):59-66.

8. Egede LE, Zheng D, Simpson K. Comorbid depression is associated with increased health care use and expenditures in individuals with diabetes. Diabetes Care. 2002;25(3):464-470. doi: 10.2337/diacare.25.3.464

9. Breslow AS, Tran NM, Lu FQ, Alpert JE, Cook BL. Depression Treatment Expenditures for Adults in the USA: a Systematic Review. Curr Psychiatry Rep. 2019;21(10):105. doi: 10.1007/s11920-019-1083-3

10. Deischinger $C$, Dervic $E$, Leutner $M$, et al. Diabetes mellitus is associated with a higher risk for major depressive disorder in women than in men. BMJ Open Diabetes Res Care. 2020;8(1). doi: 10.1136/bmjdrc-2020-001430

11. Bickett A, Tapp H. Anxiety and diabetes: Innovative approaches to management in primary care. Exp Biol Med (Maywood). 2016;241(15):1724-1731. doi: 10.1177/1535370216657613

12. Celano CM, Daunis DJ, Lokko HN, Campbell KA, Huffman JC. Anxiety Disorders and Cardiovascular Disease. Curr Psychiatry Rep. 2016;18(11):101. doi: 10.1007/s11920-016-0739-5

13. Fleury MJ, Imboua A, Aube D, Farand L. Collaboration between general practitioners (GPs) and mental healthcare professionals within the context of reforms in Quebec. Ment Health Fam Med. 2012;9(2):77-90. PMC3513700

14. Krasnov VN, Dovzhenko TV, Bobrov AE, et al. Psikhiatriya $v$ pervichnom zvene zdravookhraneniya: novoe reshenie staroi problemy. Sotsial'naya i klinicheskaya psikhiatriya. 2013;23(4):5-13.

15. Firth J, Siddiqi N, Koyanagi A, et al. The Lancet Psychiatry Commission: a blueprint for protecting physical health in people with mental illness. Lancet Psychiatry. 2019;6(8):675-712. doi: 10.1016/S2215-0366(19)30132-4

16. WHO. Mental Health Gap Action Programme (mhGAP): Scaling Up Care for Mental, Neurological and Substance Use Disorders. World Health Organization; 2008.

17. WHO. WHO Mental Health Gap Action Programme (mhGAP). World Health Organization; 2016.

18. WHO. mhGAP intervention guide for mental, neurological and substance use disorders in non-specialized health settings: mental health Gap Action Programme (mhGAP), version 2.0. World Health Organization; 2016.

19. Krasnov VN, Bobrov AE, Starostina EG, Dovzhenko TV. Razrabotka mekhanizmov kompleksnoĭ diagnostiki i poliprofessional'nogo vedeniya bol'nykh s nepsikhoticheskimi rasstrolstvami v usloviyakh pervichnogo zvena zdravookhraneniya. 2010.

20. Karpenko O, Kostyuk G. Community-based mental health services in Russia: past, present, and future. Lancet Psychiatry. 2018;5(10):778-780. doi: 10.1016/S2215-0366(18)30263-3

21. Kostyuk G, Karpenko O, Masyakin A, Burygina L. Mental health law in Russia. European Psychiatry. 2019;56:S157-S158. 
22. Bobrov AE, Kuznetsova MV. Vzaimodeistvie psikhoterapevta i uchastkovykh terapevtov polikliniki: sravnenie rezul'tatov raboty po konsul'tativnoi modeli i modeli soprovozhdeniya. Sotsial'naya i klinicheskaya psikhiatriya. 2013;23(3):72-78.

23. Martynikhin IA. The Use of ICD-10 for Diagnosing Mental Disorders In Russia, According to National Statistics and a Survey of Psychiatrists' Experience. Consortium Psychiatricum. 2021;2(2):35-44. doi: 10.17816/cp69

24. Zigmond AS, Snaith RP. The hospital anxiety and depression scale. Acta Psychiatr Scand. 1983;67(6):361-370. doi: 10.1111/j.1600-0447.1983.tb09716.x

25. Bauer M, Pfennig A, Severus E, et al. World Federation of Societies of Biological Psychiatry (WFSBP) guidelines for biological treatment of unipolar depressive disorders, part 1: update 2013 on the acute and continuation treatment of unipolar depressive disorders. World J Biol Psychiatry. 2013;14(5):334-385. doi: 10.3109/15622975.2013.804195

26. Pogosova NV, Boytsov SA, Oganov RG, et al. ClinicalEpidemiological Program of Studying Psychosocial Risk Factors in Cardiological Practice in Patients With Arterial Hypertension and Ischemic Heart Disease: First Results of a Multicenter Study in Russia. Article in Russian. Kardiologiia. 2018;17(9):47-58. doi: 10.18087/cardio.2018.9.10171

27. Pogosova NV, Boitsov SA, Oganov RG, et al. Psychosocial Risk Factors in Ambulatory Patients With Arterial Hypertension and Ischemic Heart Disease of 30 Cities in Russia: Data from the KOMETA (Comet) Study. Article in Russian. Kardiologiia. 2018;58(11):5-16. doi: 10.18087/cardio.2018.11.10193

28. Pierce $M$, Hope $H$, Ford $T$, et al. Mental health before and during the COVID-19 pandemic: a longitudinal probability sample survey of the UK population. Lancet Psychiatry. 2020;7(10):883-892

29. Simon GE, Fleck M, Lucas R, Bushnell DM, Group L. Prevalence and predictors of depression treatment in an international primary care study. Am J Psychiatry. 2004;161(9):1626-1634. doi: 10.1176/appi.ajp.161.9.1626

30. Wakida EK, Talib ZM, Akena D, et al. Barriers and facilitators to the integration of mental health services into primary health care: a systematic review. Syst Rev. 2018;7(1):211. doi: 10.1186/s13643-018-0882-7

31. Keynejad RC, Dua T, Barbui C, Thornicroft G. WHO Mental Health Gap Action Programme (mhGAP) Intervention Guide: a systematic review of evidence from low and middle-income countries. Evid Based Ment Health. 2018;21(1):30-34. doi: 10.1136/eb-2017-102750

32. Spagnolo J, Vasiliadis HM, Berbiche D, et al. The influence of primary care physicians' mental health knowledge, attitudes and self-efficacy on referrals to specialised services: findings from a longitudinal pilot trial. BJPsych Open. 2020;6(6):e130. doi: 10.1192/bjo.2020.115

33. Gureje O, Abdulmalik J, Kola L, et al. Integrating mental health into primary care in Nigeria: report of a demonstration project using the mental health gap action programme intervention guide. BMC Health Serv Res. 2015;15:242. doi: 10.1186/s12913-015-0911-3

34. Steele M, Zayed R, Davidson B, et al. Referral Patterns and Training Needs in Psychiatry among Primary Care Physicians in Canadian Rural/Remote Areas. J Can Acad Child Adolesc Psychiatry. 2012;21(2):111-123. PMC3338177

35. Wimalaratne IK, McCarthy J, Broekman BFP, et al. General hospital specialists' attitudes toward psychiatry: a cross-sectional survey in seven countries. BMJ Open. 2021;11(11):e054173. doi: 10.1136/bmjopen-2021-054173

36. Tyazhelnikov AA, Kostenko EV, Gushchin MV, Kuznetsova AS. Features of professional burnout and subjectively significant stress factors in doctors who provided remote telemedicine services during COVID-19 pandemic. Medical alphabet. 2021(33):21-25. doi: 10.33667/2078-5631-2020-33-21-25

37. Aksenova El, Shkrumyzk AR. Professional"noe vygoranie meditsinskikh rabotnikov v period pandemii. Byulleten' Nacional'nogo nauchno-issledovatel'skogo instituta obshchestvennogo zdorov'ya imeni N.A. Semashko. 2021;(4):148-155.

38. Vistorte AOR, Ribeiro WS, Jaen D, et al. Stigmatizing attitudes of primary care professionals towards people with mental disorders: A systematic review. Int J Psychiatry Med. 2018;53(4):317-338. doi: 10.1177/0091217418778620

39. Heinz I, Baldofski S, Beesdo-Baum K, et al. "Doctor, my back hurts and I cannot sleep." Depression in primary care patients: Reasons for consultation and perceived depression stigma. PLoS One. 2021;16(3):e0248069. doi: 10.1371/journal.pone.0248069

40. National Collaborating Centre for Mental Health (UK). NICE Clinical Guidelines, No. 91. Depression in adults with a chronic physical health problem: recognition and management. British Psychological Society; 2010

41. National Collaborating Centre for Mental Health (UK). Common Mental Health Disorders: Identification and Pathways to Care. British Psychological Society; 2011. 